\title{
Media sosial, komunikasi pembangunan, dan munculnya kelompok-kelompok berdaya
}

\author{
Pajar Hatma Indra Jaya \\ Universitas Islam Negeri Sunan Kalijaga, Yogyakarta, Indonesia
}

\begin{abstract}
ABSTRAK
Setiap tahun pemerintah telah mengeluarkan banyak dana untuk program pemberdayaan masyarakat, namun hasilnya belum banyak memunculkan kelompok-kelompok berdaya, apalagi menurunkan angka kemiskinan. Meskipun demikian di Yogyakarta ada beberapa komunitas yang muncul, tumbuh, dan berkembang dalam kegiatan pemberdayaan masyarakat. Salah satu komunitas berdaya tersebut adalah kelompok Mina Julantoro di Kecamatan Gedungkiwo yang mampu mengelola selokan kotor menjadi destinasi wisata. Penelitian ini bertujuan untuk mencari tahu bagaimana proses munculnya kegiatan pemberdayaan masyarakat di kelompok tersebut. Metode penelitian ini menggunakan pendekatan kualitatif deskriptif, data dikumpulkan melalui observasi, wawancara dan dokumentasi. Hasil penelitian menunjukan bahwa proses muncul dan berkembangnya pemberdayaan di kelompok Mina Julantoro terjadi karena proses peniruan dari video tentang keberhasilan program pengelolaan selokan di Singosaren Bantul yang viral dan menyebar secara cepat di media sosial. Keberhasilan program selokan bersih di Dusun Singosaren Bantul memengaruhi munculnya kegiatan serupa di tempat lain. Media sosial menjadi saluran komunikasi pembangunan dalam penyebaran gagasan positif sehingga memunculkan gerakan masyarakat untuk melakukan peniruan. Proses pemberdayaan melalui media sosial dimulai dengan pendokumentasian dalam bentuk video yang kemudian dikomunikasikan ke masyarakat luas dengan cara diunggah di YouTube dan diviralkan di grup WhatsApp. Tayangan tersebut membuat masyarakat tertarik untuk melihat, berkunjung, belajar, dan meniru. Ketika masyarakat telah mempunyai semangat dan gagasan pembangunan dari media sosial maka penyuluh pembangunan tinggal berperan sebagai enabler (pemungkin) untuk menjadi broker dan menjalankan peran teknis.
\end{abstract}

Kata-kata Kunci: Media sosial; pemberdayaan masyarakat; peniruan; komunikasi pembangunan; gagasan positif

\section{Social media, communication development, and the emergence of the empowered community}

\begin{abstract}
Every year the government has spent a lot of funds for community empowerment programs, but the results have not yet created many intended empowered groups, let alone reduce poverty. However, in Yogyakarta, several communities have emerged, grown, and developed in community empowerment activities. One such empowered community is the Mina Julantoro group in Gedungkiwo District to enable and manage dirty sewers into tourist destinations. This study aims to explore the process of the emergence of community empowerment activities in the group. This research method uses a descriptive qualitative approach, data is collected through observation, interviews and documentation. The results showed that the emergence and development of empowerment in Mina Julantoro's group occurred due to the imitation process of the video about the success of the sewer management program in Singosaren Bantul became viral and spread rapidly on social media. The clean sewer program's success in Singosaren Bantul Hamlet has influenced the emergence of similar activities elsewhere. Social media has become a development communication channel in spreading positive ideas to lead to a community movement to imitate. Through social media, the empowerment process begins with documentation in the form of videos, which then communicated to the broader community by uploading them on YouTube and going viral in the WhatsApp group. These impressions attract people to see, visit, learn, and imitate. When the community has the enthusiasm and ideas for development from social media, the development extension agent only has to act as an enabler to become a broker and carry out a technical role.
\end{abstract}

Keywords: Social media; community development; imitation; communication development; positive ideas

Korespondensi: Dr. Pajar Hatma Indra Jaya. Fakultas Dakwah dan Komunikasi, Universitas Islam Negeri Sunan Kalijaga. Jl. Marsda Adisucipto Yogyakarta 55281.Email: pajarjaya@uin-suka.ac.id 


\section{PENDAHULUAN}

Setelah lebih dari 72 tahun Indonesia merdeka, jumlah keluarga miskin masih cukup banyak. Salah satu cara yang dilakukan pemerintah untuk mengatasi kemiskinan adalah dengan pembangunan. Pembangunan merupakan sebuah usaha untuk melakukan perubahan menuju pencapaian kemakmuran rakyat. Agar proses perubahan dalam pembangunan dapat berjalan dengan arah yang benar dan dengan waktu yang cepat maka dibutuhkan perencanaan dan pendampingan. Perubahan sosial dalam pembangunan yang direncanakan dapat disebut sebagai rekayasa sosial. Penyuluh pembangunan merupakan aktor (tenaga fungsional) yang bertanggungjawab untuk merencanakan, merekayasa, mengkomunikasikan pembangunan agar berjalan baik.

Penyuluh pembangunan dapat memainkan perannya dalam bidang pemberdayaan masyarakat, yaitu mampu menjadi pendamping yang memotivasi dan memberikan dorongan bagi masyarakat sehingga mereka mau merubah perilaku berdasarkan potensi yang dimiliki dan bertindak guna tercapainya taraf hidup yang berkualitas sebagai target pembangunan (Karsidi, 2001). Peran ideal penyuluh pembangunan adalah (1) sebagai pembawa informasi atau pesan inovasi, (2) sebagai fasilitator, (3) sebagai motivator, (4) sebagai konselor (Hermawan, Amanah, \& Fatchiya, 2017).

Setiap kementerian mempunyai tenaga fungsional sebagai pendamping program pembangunan, meskipun dengan sebutan yang berbeda-beda. Di Kementerian Pertanian disebut sebagai profesi penyuluh pertanian, di Kementerian Agama dinamakan penyuluh agama, di Kementerian Desa Pembangunan Daerah Tertinggal, dan Transmigrasi muncul istilah pendamping desa profesional. Di Kementerian Sosial terdapat profesi pendamping Program Keluarga Harapan (PKH) dan pekerja sosial, di Kementerian Pekerjaan Umum dan Perumahan Rakyat terdapat istilah pendamping dan fasilitator. Selain itu terdapat juga sebutan sebagai tenaga pendamping fungsional sebagaimana digunakan di Badan Kependudukan dan Keluarga Berencana Nasional, Kementerian Kesehatan, serta Kementerian Perindustrian.
Meskipun tenaga fungsional yang tersebar di beberapa kementerian menggunakan istilah yang berbeda-beda, namun pada dasarnya mereka merupakan tenaga pendamping atau penyuluh pembangunan yang dimaksudkan untuk mempercepat proses pembangunan yang sedang dilakukan oleh pemerintah.

Jika dilihat dari segi jumlah dibagi wilayah (desa), hampir semua kementerian menyatakan bahwa tenaga pendampingnya (fungsional) masih belum ideal. Sebagai contoh di Kementerian Pertanian, jumlah penyuluh pertanian dengan status Pegawai Negeri Sipil (PNS) di seluruh Indonesia ada 25.734 orang, namun jumlah desa di Indonesia ada 81.626 sehingga masih kekurangan 55.892 orang (Badan Pusat Statistik, 2016). Di Kementerian Agama jumlah penyuluh PNS ada 4.016 orang, sedangkan jumlah desa ada 81.626. Di Kementerian Desa (PDTT) membutuhkan 10.048 pendamping desa dan baru terpenuhi 8.304 orang (Kementerian Keuangan Republik Indonesia, 2017). Selama ini kekurangan tenaga penyuluh diambilkan dari tenaga honorer atau penyuluh non-PNS. Jika penyuluh masingmasing kementerian tersebut terintegrasi dalam satu program maka bisa dikatakan jumlahnya semakin ideal (tercukupi).

Meskipun jika diakumulasi dan kolaborasi jumlah tenaga penyuluh di semua kementerian sudah cukup banyak, namun kerja penyuluh pembangunan selama ini belum optimal. Jika keberhasilan pembangunan diukur dengan jumlah angka kemiskinan maka dari tahun ke tahun angka kemiskinan di Indonesia tidak mengalami penurunan yang signifikan sehingga angkanya masih cukup tinggi. Saat ini masih terdapat 26,58 juta orang yang hidup dalam kondisi miskin (Badan Pusat Statistik, 2018). Berdasarkan data angka kemiskinan maka dapat dikatakan bahwa peran penyuluh/ fasilitator pembangunan belum berjalan secara baik. Kegagalan dalam membangun kemandirian masyarakat sering disebabkan oleh faktor kinerja penyuluh/fasilitator yang tidak profesional dan kurang handal (Mardikanto, 2013; Muslim, 2017).

Berdasarkan persoalan kekurangan jumlah fasilitator di setiap kementerian dan belum optimalnya peran penyuluh pembangunan maka dibutuhkan satu terobosan atau strategi dalam pemberdayaan masyarakat, meskipun jumlah penyuluh pembangunan kurang, namun 
perannya harus dapat dimaksimalkan. Oleh karena itu, penelitian ini tertarik untuk belajar dari keberhasilan program pemberdayaan yang berlangsung di suatu masyarakat, untuk dilihat proses apa yang menjadi kunci keberhasilan suatu program pemberdayaan masyarakat.

Salah satu komunitas yang muncul, tumbuh, berkembang, dan menjadi berdaya berada di Kampung Dukuh, Kelurahan Gedongkiwo, Kecamatan Mantrijeron, Kota Yogyakarta. Masyarakat Dukuh mampu merubah selokan penuh sampah menjadi selokan bersih penuh dengan ikan sehingga menjadi destinasi wisata. Masyarakat Gedongkiwo mampu melakukan transformasi dari masyarakat yang mempunyai masalah menjadi masyarakat yang mampu mengolah selokannya menjadi aset yang berharga, khususnya di bidang perikanan dan pariwisata. Keberhasilan masyarakat Gedongkiwo ini dapat dilihat dari video yang diunggah di Brilio.net dan beredar di WhatsApp dengan judul Dulu Bau dan Kotor, Selokan di Jogja Ini Berubah Cantik Bak di Jepang (Salim, 2018) dan juga di YouTube dengan judul Selokan Kotor Disulap Cantik Penuh Ikan. Penelitian ini bertujuan untuk menjelaskan bagaimana proses munculnya kegiatan pemberdayaan masyarakat di kelompok tersebut sehingga Kampung Dukuh Gedongkiwo menjadi kelompok yang berdaya dalam menyelesaikan masalah sampah.

\section{METODE PENELITIAN}

Penelitian ini dilakukan di kelompok Mina Julantoro yang berada di Kampung Dukuh (RT 69/RW 14 dan RT 62/RW 12), Kelurahan Gedongkiwo, Kecamatan Mantrijeron, Yogyakarta. Lokasi ini diambil karena mulai bulan November 2017 kelompok ini mampu mengelola saluran air yang melewati kampung sepanjang 200 meter dengan budidaya ikan nila merah dan menjadikannya sebagai salah satu destinasi wisata baru di Yogyakarta. Padahal sebelumnya selokan tersebut penuh dengan sampah.

Untuk mendapatkan jawaban proses pemberdayaan, peneliti menggunakan pendekatan deskriptif kualitatif (Sugiyono, 2013). Data dikumpulkan dengan menggunakan observasi, wawancara, dan dokumentasi. Teknik dokumentasi dilakukan dengan cara menggali berita koran dan media sosial tentang Mina
Julantoro. Setelah itu dilakukan observasi.

Observasi pertama dilakukan dengan cara berperan sebagai pengunjung seperti masyarakat lainnya. Kunjungan ini membuat peneliti dapat menggali informasi dari salah satu pengelola yang belum peneliti kenal. Setelah mengetahui suasana alami selokan edukasi, peneliti baru menghubungi Bapak Sumiran (Ketua Dua Mina Julantoro Asri) sebagai informan kunci. Peneliti sudah mengenal Bapak Sumiran karena sering diskusi di FKWA (Forum Komunikasi Winongo Asri) Yogyakarta.

Dari wawancara dengan Bapak Sumiran peneliti diberi beberapa nama informan untuk melengkapi data. Selain itu peneliti juga diminta hadir untuk langsung bertemu dengan seluruh pengurus kelompok Mina Julantoro Asri, penyuluh perikanan/Dinas Perikanan dan Kelautan DI (Daerah Istimewa) Yogyakarta, dan juga pemerintah setempat pada saat panen ikan. Dalam penelitian, teknik penentuan informan ini disebut sebagai teknik bola salju yang mana Bapak Sumiran menjadi informan kunci.

Dari data yang telah terkumpul peneliti melakukan proses validitas data dengan teknik triangulasi sumber dan metode. Data yang telah valid kemudian peneliti susun menjadi deskripsi berupa runtutan peristiwa dan dilakukan analisis kembali untuk menarik kesimpulan (Moleong, 2017).

\section{HASIL DAN PEMBAHASAN}

Kampung Dukuh mempunyai selokan yang membelah tepat di tengah kampung. Selokan tersebut bernama Selokan Tanjung Kiri yang merupakan anak Sungai Winongo. Selama ini Selokan Tanjung banyak terkotori oleh sampah rumah tangga. Sampah seolah-olah menjadi identitas baru sungai-sungai di Yogyakarta karena hampir semua bantaran sungai di Yogyakarta terdapat banyak endapan sampah plastik.

Menurut penelitian Jenna R. Jambeck Indonesia diperkirakan termasuk penyumbang sampah plastik di laut terbesar ke dua di dunia setelah China (Jambeck et al., 2015). Meskipun Dinas Lingkungan Hidup DI Yogyakarta mempunyai program mertikali, gotong royong membersihkan sampah di sungai, namun sebagian besar bantaran sungai di Yogyakarta terlihat banyak sampah plastiknya. Sampah- 
sampah plastik tersebut mengalir sampai ke laut.

Berdasarkan persoalan banyaknya sampah di Selokan Tanjung membuat masyarakat mencari ide bagaimana cara agar persoalan sampah dapat diatasi. Sejak bulan November 2017 tiga puluh orang warga Kampung Dukuh Gedongkiwo mulai berusaha mengatasi persoalan sampah plastik dengan memfungsikan selokan tidak sekedar sebagai saluran irigasi ke sawah-sawah petani, namun selokan tersebut ditebari ikan nila merah. Dengan adanya ikan nila membuat warga setiap hari rajin ke sungai untuk memberi makan ikan. Intensitas warga yang rajin ke sungai ditambah dengan pembuatan papan pengumuman pelarangan buang sampah ke sungai membuat warga sekitar yang biasa membuang sampah ke sungai mulai segan. Dengan demikian setelah program pelihara ikan tersebut berjalan, persoalan sampah mulai teratasi. Warga saat ini "seakanakan" menjadi tim penjaga sungai dari sampah.

Selain mendapat lingkungan menjadi bersih, pengelola juga mendapatkan keuntungan ekonomi berupa usaha pembesaran ikan nila dan jualan pakan. Setelah selokan diberi ikan nila merah banyak masyarakat yang berbondong-bondong untuk melihatnya. Selain berswafoto mereka juga memberi makan ikan. Pakan nila dijual kepada masyarakat yang berkunjung "tamasya" ke lokasi dalam bentuk bungkusan kecil seharga Rp1.000,00. Banyaknya pengunjung yang datang membuat pemilik kolam terbantu dalam pengeluaran biaya untuk makan ikan. Dalam waktu tiga setengah bulan hasil dari pembelian pakan ikan oleh pengunjung bernilai lebih dari Rp2 juta rupiah.

Mulai berkurangnya ruang publik dan tempat rekreasi yang murah di Yogyakarta menjadikan selokan menjadi alternatif tempat wisata keluarga. Kondisi wisata ini didukung dengan kegemaran masyarakat saat ini untuk berswafoto dan mengunggahnya di media sosial. Ketika peneliti berkunjung ke lokasi dijumpai beberapa kelompok remaja yang berswafoto dan ada yang sedang merayakan ulang tahun di pinggir Selokan Tanjung Kiri.

Berdasarkan wawancara dengan Bapak Sumiran, ide dari kegiatan budidaya nila di Selokan Tanjung Kiri karena melihat tayangan video pemanfaatan selokan yang tersebar di media sosial (Sumiran, 2018). Video di media

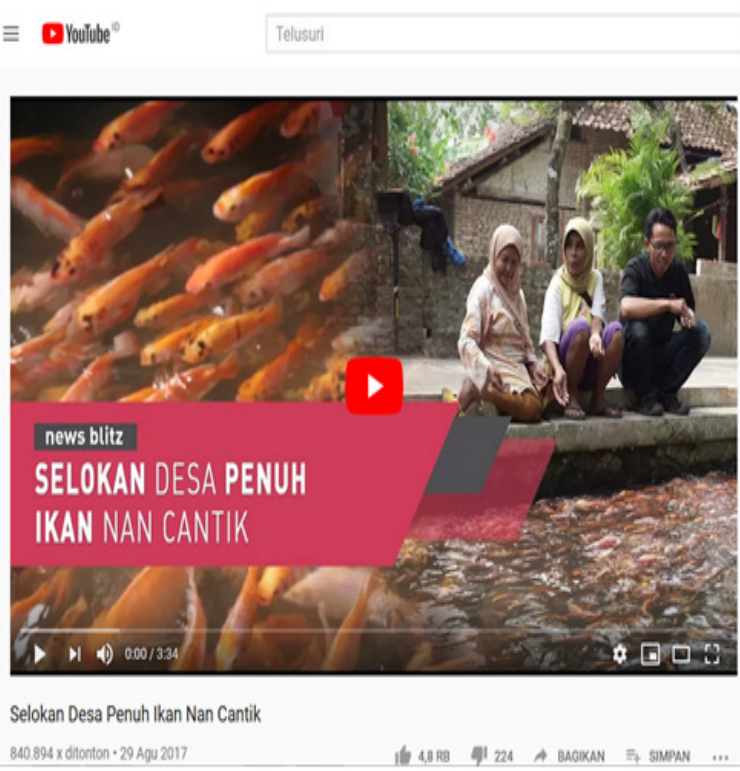

Sumber:YouTube, 29 Agustus 2017

\section{Gambar 1 Video yang Menginspirasi Munculnya Pembangunan di Gedongkiwo}

sosial tersebut menggambarkan keberhasilan masyarakat Dusun Singosaren Bantul dalam mengubah selokan yang kumuh menjadi selokan bersih seperti gambaran selokan di Jepang. Di YouTube, video budidaya nila di selokan tersebut diberi judul Selokan Desa Penuh Ikan Nan Cantik: Bikin Warga Pikir Ulang Buang Sampah Sembarangan, dapat dilihat pada gambar 1 .

Video berdurasi 03:34 menit tersebut pertama kali diunggah di www.brilio.net (Putradinata, 2017) dan disebarkan secara berantai melalui media sosial WhatsApp, Facebook, dan YouTube. Persoalan yang dihadapi oleh masyarakat Dusun Singosaren sama dengan yang dihadapi masyarakat Gedongkiwo, yaitu sampah sehingga solusi dan keberhasilan yang telah dilakukan oleh masyarakat Singosaren dirasakan akan cocok jika diterapkan di Gedongkiwo.

Gambaran selokan bersih di media sosial yang ada di Singosaren memunculkan keinginan warga Gedongkiwo untuk menirunya. Mereka kemudian membicarakan dalam pertemuan-pertemuan masyarakat dan sepakat untuk mengorganisir diri dengan membentuk kelompok Mina Julantoro Asri yang beranggotakan 30 orang.

Nama Mina Julantoro Asri terdiri dari tiga kata, kata Mina berarti ikan, Julantoro 
merupakan nama jembatan tua yang legendaris di atas Selokan Tanjung Kiri dan Sungai Winongo. Jembatan tersebut menjadi ikon Gedongkiwo. Kata Asri dipilih karena mereka tinggal dan merasa sebagai bagian dari kata Winongo (Forum Komunikasi Winongo Asri/ FKWA). Ketua kelompok Mina Julantoro Asri saat ini adalah Pak Rohmat (Ketua RT) dan ketua duanya Bapak Sumiran (anggota FKWA).

Sebelum selokan dikelola seperti saat ini, beberapa warga sebenarnya telah memanfaatkan Selokan Tanjung Kiri untuk kegiatan ekonomi produktif dengan cara membuat karamba. Namun kehadiran karamba-karamba tersebut menjadi penghalang aliran air irigasi ke lahanlahan pertanian. Bahkan karamba-karamba tersebut juga menjadi penghalang bagi laju sampah-sampah dari Sungai Winongo ke laut sehingga sampah berhenti di tengah karamba dan mengotori selokan. Berdasarkan tayangan video tentang selokan bersih di Singosaren membuat masyarakat Gedongkiwo tertarik untuk mencoba menirunya. Sistem budidaya ikan nila di selokan Dusun Singosaren dilakukan dengan membuat jaring-jaring dan alat pengangkat sampah. Dengan demikian masyarakat tidak hanya mendapat keuntungan ekonomis dari budidaya nila, namun sistem tersebut turut melibatkan masyarakat untuk ikut membersihkan sungai. Ide dari budidaya ikan di selokan Singosaren membuat masyarakat sadar sehingga mereka bersedia untuk mengganti karamba dengan jaring. Pergantian sistem budidaya tersebut membuat aliran irigasi selokan ke sawah petani semakin lancar. Penggantian model budidaya ikan dari karamba menjadi jaring juga tidak merugikan masyarakat yang selama ini telah mempunyai usaha budidaya ikan model karamba karena mereka turut dilibatkan dalam perubahan cara budidaya ikan tersebut.

Setelah menemukan ide pengelolaan selokan dari video di Singosaren, Pak Rohmat menyempatkan diri untuk melihat secara langsung selokan penuh ikan yang ada di Singosaren. Dari kunjungan tersebut disusunlah keinginan untuk meniru dengan membuat perencanaan bersama masyarakat. Berdasarkan hasil pertemuan disepakati untuk dibuat rencana besar pengelolaan Selokan Tanjung Kiri yang dikomunikasikan dengan pemerintah desa dan provinsi. Sebagai tindak lanjut dari rencana tersebut, masyarakat menghubungi pemerintah
(Dinas Perikanan dan Kelautan) DI Yogyakarta agar bersedia membantu mewujudkan mimpi masyarakat. Dinas Perikanan dan Kelautan DI Yogyakarta dipilih karena berdasarkan tayangan video di Singosaren diceritakan bahwa sebagian ikan dibantu oleh Dinas Perikanan dan Kelautan Provinsi.

Menanggapi permintaan masyarakat untuk meniru selokan bersih yang ada di Singosaren maka tim penyuluh dari Dinas Perikanan dan Kelautan DI Yogyakarta melakukan assessment lapangan. Berdasarkan persoalan dan potensi yang ada di Gedongkiwo, dinas melihat bahwa ada peluang besar untuk melakukan peniruan. Apalagi wilayah Gedongkiwo merupakan wilayah perkotaan yang dekat dengan akses pemerintahan, belum ada selokan penuh ikan di wilayah kota, aliran air yang lancar dan mengalir sepanjang waktu, serta mempunyai persoalan sampah membuat dinas menyepakati usulan masyarakat. Dinas Perikanan dan Kelautan DI Yogyakarta memberikan daya kepada masyarakat berupa bantuan sosial berwujud barang (ikan nila merah sebanyak 15.000 ekor, pakan, alat pompa, dan sebagainya) senilai Rp.50 juta.

Penyuluh (dinas) berfungsi sebagai enabler, pemungkin ketika masyarakat telah mempunyai ide yang menarik. Perubahan sosial sering dimulai dengan adanya ide yang menarik dan perubahan cara berfikir masyarakat. Selain itu penyuluh perikanan juga menjalankan peran teknis terkait dengan bagaimana cara budidaya nila yang baik di masyarakat. Mereka ikut memberikan informasi teknis tentang pemeliharaan nila dalam pertemuan-pertemuan kelompok yang rutin dilakukan setiap tiga puluh lima hari sekali. Namun ide awal dari gerakan selokan cantik penuh ikan di Gedongkiwo adalah peniruan dari video yang viral di media sosial.

Peniruan merupakan salah satu strategi paling mudah untuk memulai program pemberdayaan masyarakat. Tulisan-tulisan terdahulu juga menekankan peniruan dalam pembangunan. Bahkan konsep pembangunan (development) pertama menggunakan konsep peniruan. Pada tanggal 20 Januari 1949, Presiden Amerika Harry Truman menyampaikan konsep tentang pembangunan "fair deal" for entire world. Truman menyampaikan bahwa di banyak negara muncul masalah kemiskinan, kekurangan makanan, dan juga penyakit yang 
tidak lagi dijumpai di Amerika, oleh karena itu Amerika sebagai negara besar harus membantu mereka dalam pembangunan. Salah satu cara yang paling mudah untuk mewujudkan pembangunan di negara dunia ketiga adalah dengan meniru keberhasilan pembangunan di negara maju. Gerakan ini kemudian dikenal dengan istilah modernisasi. Untuk melakukan pembangunan negara dunia ketiga cukup meniru proses pembangunan (modernisasi) dari Amerika (Escobar, 1995).

Di tingkat teoritis peniruan ini dituliskan dalam teori pembangunan Rostow. Secara rinci Rostow menuliskan lima tahap pembangunan yang harus diikuti negara berkembang untuk melakukan pembangunan-belajar dari Amerika (Escobar, 1995). Di tingkat lokal peniruan ini menjadi sesuatu yang penting, Ki Hajar Dewantara menekankan konsep belajar melalui niteni, nirokake, nambahi sebelum nemokke atau dalam bahasa Indonesia sering disebut dengan ATM (Amati, Tiru, Modifikasi) sebelum dapat membuat penemuan baru. Penjelasan ini juga dibenarkan dalam penelitian Jaya ketika memeriksa desa-desa berdaya di beberapa tempat di Yogyakarta (Jaya, 2012). Keberhasilan usaha satu orang menyebabkan keinginan masyarakat lainnya untuk meniru (trickle down efeck) sehingga satu kampung menjadi sentra kerajinan, seperti desa peyek di Pelem Madu, desa gerabah di Kasongan, desa batik di Pandak Bantul. Hal yang sama juga terjadi dalam penyulapan kampung kumuh menjadi indah. Hal ini misalnya peniruan Kampung Jodipan di Malang oleh Kampung Pelangi Randusari, peniruan oleh warga Dusun Pabyongan, ditiru di Kawasan Kenjeran, dan juga oleh masyarakat Linggau Ulu Sumatera Selatan (Kompas, 2018). Oleh karena peniruan merupakan salah satu cara yang ampuh untuk menuangkan ide/ gagasan pembangunan maka di banyak tempat diperlukan kegiatan studi banding mendatangi dan belajar dari daerah yang sudah menerapkan dan berhasil dalam pembangunan.

Komunikasi dalam pembangunan dimaksudkan untuk penyebaran gagasangagasan pembangunan. Terjadi pergeseran komunikasi pembangunan dari komunikasi yang dahulu hanya bersifat tatap muka secara langsung (face to face) menjadi komunikasi massa. Komunikasi massa dapat diartikan sebagai penyampaian pesan secara masal kepada masyarakat luas dengan menggunakan media massa. Media massa mempunyai keunggulan karena menjangkau wilayah yang sangat luas, bahkan mempunyai pengaruh yang tidak kalah dengan komunikasi secara langsung. Media massa, seperti surat kabar, radio, dan televisi sudah sejak lama digunakan sebagai sarana komunikasi pembangunan di Indonesia.

Di era Orde Baru, program siaran Kelompencapir (Kelompok Pendengar, Pembaca, dan Pemirsa) di TVRI digunakan sebagai sarana untuk mengenalkan perkembangan teknologi pertanian (pembangunan) ke masyarakat luas. Televisi mempunyai kemampuan mempengaruhi perilaku sehari-hari masyarakat. Studi-studi tentang iklan di televisi menunjukan korelasi yang positif antara iklan di televisi dengan besar kecilnya pembelian suatu produk (Sugiyanto, 2012). Di masa lalu perkembangan media massa, televisi dan film juga telah memporak-porakan tradisi. Media masa mempunyai kemampuan untuk mempengaruhi kebudayaan dan menjadi pemicu perubahan sosial (Kango, 2015).

Namun sejak jaringan internet menjangkau banyak areal di Indonesia, media sosial merupakan sarana yang mudah, murah, mempunyai kecepatan, dan jangkauan yang sangat luas untuk menyebarkan pengetahuan baru. Dibandingkan dengan televisi, biaya berkomunikasi lewat media sosial jauh lebih murah. Komunikasi dengan menggunakan televisi biasanya juga bersifat satu arah (top down), dari pemerintah ke masyarakat. Masyarakat hanya sebagai objek atau penerima pesan, namun dengan teknologi informasi (media sosial) siapa saja dengan mudah mendapatkan akses untuk menyebarkan informasi atau gagasan secara umum ke masyarakat. Dengan munculnya media sosial, semua orang bisa jadi komonikator sekaligus komunikan. Semua orang bisa memproduksi dan menyebar informasi. Penyuluh bisa memanfaatkan perkembangan teknologi komunikasi sesuai kepentingan kepenyuluhan. Komunikator dalam media sosial juga tidak terjebak pada bahasa ilmiah yang sulit dipahami masyarakat awam, sebagaimana sering terjadi dalam komunikasi pembangunan di media televisi dan radio (Widjanarko, Sulthan, \& Lusiana, 2013).

Pengaruh media sosial juga tidak kalah kuat dibanding televisi. Beberapa penelitian menunjukan bagaimana kuatnya pengaruh 
media sosial terhadap perubahan sosial di suatu masyarakat. Salah satu temuan yang paling fenomenal dari pengaruh media sosial ke masyarakat adalah kaitan antara media sosial dengan terjadinya revolusi politik di banyak negara kawasan Timur Tengah (the Arab Spring Countries' Revolutions) (Miladi, 2016). Penggunaan media sosial juga efektif dimanfaatkan untuk menyebarkan gagasan gerakan sosial mengkampanyekan program menyusui anak (Hartoyo \& Supriadi, 2015). Di ranah yang lebih kecil, media sosial Facebook, Instagram, dan sistem aplikasi Lazada terbukti mampu digunakan sebagai saluran untuk mendongkrak penjualan suatu produk (Reza, 2016; Triyono, 2011; Yasundari, 2016).

Jika dahulu media sosial hanya dijadikan sebagai saluran komunikasi alternatif, saat ini media sosial telah menjadi alat pemasaran mainstream meskipun tidak menggantikan model pemasaran tradisional. Media sosial mampu menjadi penghubung (jejaring) masyarakat secara masif, bahkan ketika komunikasi tanpa disengaja diarahkan oleh komunikator kepada segmen masyarakat tertentu (komunikan), namun pengaruh tersebut bisa masuk ke kelompok tersebut. Media sosial mudah sekali menyebar kemana saja tanpa dibatasi cakupan geografi dan bisa digunakan secara aktif ataupun pasif (Moriansyah, 2015).

Penyebaran gagasan gerakan selokan bersih penuh ikan di Gedongkiwo juga muncul sebagai hasil dari penggunaan media sosial. Proses pengorganisasian yang terjadi di Gedongkiwo terpengaruh dengan tayangan video pengelolaan selokan di Dusun Singosaren, Wukirsari, Imogiri, Bantul. Tayangan tersebut diupload pada tanggal 29 Agustus 2017 oleh Brilio.Net yang kemudian (sudah) ditiru oleh masyarakat Gedongkiwo pada bulan November tahun 2017. Hanya membutuhkan waktu tiga bulan setelah diunggah di YouTube dan viral di media sosial, tayangan video pemberdayaan di Singosaren ditiru oleh masyarakat di tempat lain. Masyarakat Gedongkiwo tergerak pertama kali bukan karena dorongan dari penyuluh pembangunan, namun secara alamiah tertarik oleh ide tayangan video dari media sosial.

Tayangan yang baik ini memberikan asosiatif kepada para pemirsanya. Masyarakat Gedongkiwo merasa bahwa apa yang dilakukan di dalam tayangan video di Singosaren bisa diterapkan di komunitasnya. Mereka berasosiasi berdasar pada aset-potensi yang dimiliki danjuga berdasar pada masalah yang dihadapi, keduanya mempunyai kemiripan. Mereka menyadari bahwa persoalan sungai adalah persoalan sampah yang sekarang terjadi di hampir semua sungai di Yogyakarta. Selain itu mereka menyadari bahwa solusi di Singosaren bisa dipraktikan di Gedongkiwo karena mempunyai aset yang sama berupa sungai yang mengalir setiap hari. Selain itu mereka mempunyai daya pikir untuk membayangkan serta harapan (hope) bahwa dengan meniru praktek yang divideokan tersebut maka persoalan sampah di Gedongkiwo dapat diatasi, bahkan mereka juga bisa mengembangkan dengan varian yang lebih menarik. Pak Sudarto (Penasehat Mina Julantoro, sekaligus Ketua RW) menyampaikan imajinasinya bahwa pengelolaan selokan belum dirasa cukup, namun beliau mempunyai harapan bahwa selokan di Gedongkiwo dapat berkembang lebih hebat dari Singosaren karena potensi yang dimilikinya. Pak Sudarto memikirkan di masa yang akan datang akan berusaha menumbuhkan kuliner ikan, kawasan wisata bunga, dan perahu di Selokan Tanjung Kiri dan Sungai Winongo (Sudarto, 2018). Hal yang sama disampaikan oleh Bapak Sumiran:

"Dari video kita berusaha untuk meniru proses yang terjadi di Singosaren mas. Setelah kita sepakat, kita tindak lanjuti dengan studi banding ke lokasi. Kita berharap nantinya di sepanjang sungai akan ada gazebo/joglo, serta tanaman-tanaman bunga sehingga lebih baik dari lokasi yang kita tiru" (Sumiran, 2018).

Tayangan video selokan cantik di Singosaren, Wukirsari Bantul bahkan pada tahun 2017 membuat bupati Bantul tertarik untuk berkunjung ke lokasi tersebut dan berjanji akan memfasilitasi serta membuat gerakan serupa di kampung-kampung lain di Bantul. Saat ini video tersebut juga turut mempengaruhi program serupa di beberapa wilayah. Selain di Gedongkiwo Yogyakarta, terjadi juga peniruan di Dusun Manggung Bantul dan Kampung Gendeng Kota Yogyakarta.

Kerja dari pemberdayaan masyarakat di Gedongkiwo saat ini juga telah didokumentasikan dalam bentuk video oleh Brilio dan diunggah ke YouTube. Setelah itu disebarkan melaui media sosial WhatsApp. Berita-berita yang diunggah melalui WhatsApp 
lebih mudah tersebar karena media ini termasuk media paling praktis dan murah dalam berkomunikasi. Tidak memakan waktu lama, video selokan penuh ikan di Gedongkiwo sudah ditonton oleh banyak orang. Sejak diunggah di YouTube pada tanggal 8 Maret 2018, sampai tanggal 18 Maret 2018 atau hanya dalam waktu 10 hari video tersebut telah ditonton oleh 758 orang. Bahkan tayangan di media sosial tersebut membuat tertarik sejumlah media massa yang lain untuk meliputnya, seperti Tribun, Radar Jogja, RBTV, ADiTV.

Penelitian ini menemukan bahwa media sosial ternyata merangsang masyarakat untuk tergerak dalam memberdayakan wilayahnya. Semakin banyak tayangan inovatif yang beredar di masyarakat akan membuat orang mudah menemukan ide tentang mimpi kedepan, apa yang akan dilakukan untuk pembangunan wilayahnya. Sebuah tayangan video/film dalam pembelajaran menjadi alat bantu karena di dalamnya terdapat visualisasi dan suara sehingga pesannya mudah ditangkap. Oleh karena tayangan videonya dianggap baik dan mempunyai muatan virus N-Ach (motivasi berprestasi) maka tayangan tersebut berdampak pada peniruan. Dalam kacamata teori modernisasi, video budidaya ikan di selokan membangkitkan motivasi dan mempunyai muatan motivasi berprestasi (Need of Achivment) yang tinggi. David McClaland menggunakan istilah Virus N-Ach (Need of Achivment) yang menjadi kata kunci pembangunan di banyak peradaban.

Buchori menyampaikan bahwa kemiskinan punya korelasi positif dengan "kemiskinan pengetahuan". Mereka yang miskin pengetahuan adalah orang-orang yang juga buta terhadap pengalaman-pengalaman pembangunan di daerah lain sehingga juga akan menyebabkan miskin gagasan atau ide (Buchori, 2006). Oleh karena itu penting sekali untuk memberikan pengetahuan ke masyarakat sehingga masyarakat tidak miskin pengetahuan. Demikian juga tergeraknya masyarakat untuk berkegiatan dan munculnya program pemberdayaan masyarakat mempunyai hubungan dengan pengetahuan yang muncul di masyarakat. Salah satu peran yang penting dan harus dimainkan penyuluh pembangunan adalah fungsi sebagai pemberi informatif atau edukasi kepada masyarakat. Penyuluh harus mampu memberikan pengetahuan kepada dampingannya agar mereka mau mengadopsi pilihan inovasi pengetahuan untuk dipraktikan demi peningkatan kesejahteraan masyarakat.

Fungsi penyuluh sebagai pemberi informasi dan edukasi kepada masyarakat akan temuan baru hasil penyelidikan pertanian kepada masyarakat sebenarnya merupakan fungsi pertama yang diberikan oleh pemerintah kepada para penyuluh. Pemberian amanat terkait peran penyuluh tersebut telah dimulai sejak tahun 1905, bersamaan dengan berdirinya Departemen Pertanian (Van Landbouw) di masa penjajahan (Karsidi, 2001). Peran tersebut sampai saat ini masih disematkan kepada penyuluh pertanian, bersamaan dengan pemberian peran lainnya, yaitu sebagai fasilitator, motivator, dan konselor. Meskipun demikian dari empat peran tersebut, menurut penelitian Hermawan, Amanah, Fatchiya menemukan bahwa peran sebagai educator dan fasilitator belum berjalan baik dibanding peran penyuluh sebagai motivator dan konselor. Padahal peran sebagai edukator pembawa informasi inovasi merupakan peran yang disematkan pertama kali kepada para penyuluh. Banyak perubahan dalam pembangunan juga diawali dengan munculnya ide dan perubahan cara berfikir (Hermawan et al., 2017).

Mardikanto menyatakan bahwa media massa lebih efektif dan lebih murah untuk mengenalkan suatu inovasi. Semakin banyak media yang digunakan untuk menyampaikan satu informasi baru maka akan memberikan pengaruh semakin baik dan semakin jelas informasi yang diterima sehingga akan semakin banyak orang mengerti inovasi tersebut dan pada akhirnya dapat melaksanakannya. Penyebaran informasi (komunikasi) yang baik dalam kegiatan kepenyuluhan menjadi pemicu terjadinya perubahan pengetahuan dan pandangan sehingga dapat mempengaruhi perubahan atas model produksi yang akhirnya dapat memberikan peningkatan kesejahteraan. Di era perkembangan teknologi komunikasi informasi(ICT) yang semakin pesat, komunikasi dengan memanfaatkan gawai dan dukungan akses informasi dan aksesibilitas pelayanan yang semakin baik dapat menjembatani kesenjangan sumberdaya manusia yang ada di pelosok (desa) dengan daerah-daerah yang lebih maju (Mardikanto, 2009).

Hal ini didukung dengan jumlah kepemilikan gawai yang terhubung dengan 
internet (smart phone) di Indonesia yang diperkirikan telah mencapai 143 juta orang (Bohang, 2018). Banyaknya pengguna smartphone ini mempengaruhi kecepatan (viralnya) tayangan video, termasuk berita hoaks. Media sosial dapat menyebarkan berita di atas kecepatan cahaya. Dunia semakin sempit, masyarakat saat ini semakin mudah terkoneksi satu dengan yang lain. Mereka terhubung antara satu dengan yang lain melalui kelompok media sosial, seperti WhatsApp. Saat ini rata-rata satu orang pemilik gawai mempunyai lebih dari lima grup media sosial. Informasi yang disampaikan dari satu grup media sosial akan di copy paste-disebarkan ke grup lainnya sehingga media sosial mempunyai kecepatan memindah informasi seperti kecepatan cahaya.

Penggunaan media sosial untuk menyebar gagasan tidak hanya berjalan seperti lampu pijar. Lampu pijar mempunyai sifat semakin dekat dengan sumber lampu maka pengaruhnya akan semakin kuat, namun penelitian ini menemukan bahkan di lokasi yang jauh sekalipun juga banyak masyarakat yang terinspirasi untuk melakukan peniruan dari video program pengelolaan selokan yang dibuat di Singosaren. Penataan selokan bersih bahkan terinspirasi dari ide selokan yang ada di Jepang. Meskipun warga ingin meniru selokan-selokan di Jepang, namun mereka belum pernah pergi ke Jepang. Bahkan mereka juga tidak pernah berdiskusi dengan orang Jepang. Mereka hanya mencari referensi video terkait selokan di Jepang dan melakukan peniruan (copy cate). Dengan tidak datang langsung ke lokasi membuat mereka mempunyai dugaan-dugaan dan imajinasi yang kadang melampaui kondisi aslinya (di Jepang).

Ada proses modifikasi yang membuat mimpi tersebut cocok dan bisa diterapkan dimana masyarakat itu berada. Salah satu modifikasi yang diterapkan di Singosaren dan Gedongkiwo dari model di Jepang adalah proses pemberian makan ikan. Selokanselokan di Jepang diisi dengan ikan koi, oleh karena ikan koi merupakan ikan yang peka terhadap kebersihan air maka pengunjung tidak diperbolehkan memberi makan kepada ikan tersebut. Namun karena yang dipelihara di Singosaren dan Gedungkiwo merupakan ikan nila maka mereka memodifikasi dengan pengunjung diperbolehkan memberi makan ikan. Bahkan kegiatan memberi makan ikan ini mampu memberikan tambahan pendapatan bagi masyarakat.

Menurut salah satu informan yang melihat tayangan video di Singosaren mengatakan bahwa gambaran yang terjadi di lapangan tidak seindah gambaran yang ada di video. Video tidak sekedar menggambarkan kenyataan yang sama persis, namun tayangan video hanya menyuguhkan sudut-sudut yang paling menarik dari suatu peristiwa. Hal ini sesuai dengan konsep nilai berita, dalam teori komunikasi informasi yang menjadi berita merupakan suatu informasi yang baru, spesial, menarik, dan unik (aneh) (Koespradono, 2017). Dengan demikian ketika gambar-gambar di lapangan kemudian disusun dalam satu sudut cerita tertentu maka potongan-potongan tersebut menjadi film utuh yang terkadang bisa melebihi gambaran aslinya. Hal yang melebihi aslinya ini tidak hanya berefek menyesatkan, namun terkadang mempunyai efek positif untuk menyangatkan sehingga pemirsa akan cenderung untuk mengikutinya. Bahkan terkadang peniru bisa memodifikati dari realitas yang ada.

Jarak antara Singosaren dengan Gedongkiwo kurang lebih $15 \mathrm{~km}$. Dengan demikian dalam peniruan ini gagasannya tersebar cukup jauh. Bahkan menurut informasi dari Pak Sumiran ada juga warga NTT yang telah berkunjung dan ingin menerapkan di daerahnya. Warga NTT tersebut mengetahui Gedongkiwo dari tayangan di media sosial. Media sosial punya kecepatan sebar yang melebihi berita surat kabar (Sumiran, 2018).

Gerakan selokan bersih di Singosaren diunggah di YouTube oleh Brilio pada tanggal 29 Agustus 2017 dan pada tanggal 26 Maret 2018 telah ditonton oleh 309.693 orang (37.167 subcriber/berlangganan). Video dari Brilio tersebut juga diunggah di YouTube oleh Life Hacking pada tanggal 30 Agustus 2017 dan pada tanggal 26 Maret 2018 telah ditonton oleh 918.355 orang atau lebih banyak dari video yang diupload oleh Brilio sendiri. Meskipun demikian gerakan memelihara ikan di selokan untuk mengatasi sampah sebenarnya telah muncul terlebih dahulu di Klaten. Gerakan di Klaten juga sudah dibuat video yang diunggah di www.brilio.net dan YouTube dengan judul Selokan Cantik Klaten Ala Jepang. Video selokan bersih ala Klaten yang diunggah di YouTube 27 Februari 2017 ini telah dilihat oleh lebih dari setengah juta masyarakat pada tanggal 26 Maret 2018. Sebelumnya gerakan 
yang mirip juga sudah muncul di Klodran, Karanganyar. Gerakan selokan bersih di Klodran, Karanganyar juga sudah muncul di YouTube sejak 11 September 2017 dengan judul Kece, Warga Karanganyar Ubah Selokan Penuh Sampah Jadi Kolam Ikan dan telah ditonton oleh lebih dari 1 juta orang dan 28.240 subscriber pada tanggal 26 Maret 2018. Gerakan irigasi bersih penuh dengan ikan nila ini di Klodran Karanganyar Jawa Tengah telah ada sejak tahun 2008 dan digagas oleh Bambang Agus. Jadi wajar jika lokasi-lokasi yang telah berhasil dalam pemberdayaan masyarakat tersebut dikunjungi oleh banyak orang dari berbagai daerah karena tayangan videonya telah ditonton oleh ribuan orang dan video tersebut dapat dinikmati dimana saja asalkan tersedia jaringan internet.

Dengan demikian, kegiatan pemberdayaan masyarakat dengan basis media sosial tidak mengenal batas ruang dan waktu. Selama di suatu daerah terdapat gawai dan jaringan internet maka video tersebut dapat ditonton dan dapat mempengaruhi suatu kelompok untuk mengaplikasikan di daerah lain. Jika masyarakat telah menemukan gagasan lewat video di media sosial maka penyuluh pembangunan di setiap lokasi tinggal mendorong untuk dihubungkan (broker) dengan pemerintah sebagai pemilik aset keuangan. Penyuluh pembangunan bertindak sebagai pemungkin (enabler) untuk menguatkan dan mewujudkan mimpi masyarakat.

Beberapa penelitian menunjukan bahwa kendala utama penyuluh untuk menjalankan fungsinya dengan baik ada di aspek luasnya wilayah binaan. Meskipun penyuluh di Indonesia sudah ada di setiap kecamatan, mempunyai pendidikan yang cukup baik, motivasi psikologi yang kuat untuk menjadi penyuluh, namun luas wilayah yang menjadi binaanya menjadi penghalang kinerja mereka (Banunaek, Suminah, \& Karsidi, 2017). Dengan pembuatan video profil keberhasilan satu kelompok dalam pembangunan dan menyebarkannya ke grup dampingan maka persoalan wilayah binaan yang luas tidak lagi menjadi kendala. Penelitian Muhammad Ilham Bakhtiar juga menunjukan bahwa video merupakan alat yang fungsional dan memudahkan orang untuk mendapatkan pemahaman, termasuk di dunia pendidikan (Bakhtiar, 2015). Penyuluh pembangunan tinggal membekali dirinya dengan kemampuan membuat video. Saat ini untuk membuat video tidak lagi hanya bisa dilakukan oleh tenaga profesional karena pembuatan video tidak lagi membutuhkan alat yang mahal dan waktu editing yang lama. Gawai zaman sekarang sudah mempunyai kemampuan untuk merekam gambar yang baik, menginstal softwere editing video secara gratis, dan mempunyai kemampuan menyebarkannya ke media sosial. Dibutuhkan waktu kurang dari setengah jam untuk memproduksi video dengan durasi lima menit.

Dengan membuat video akan keberhasilan suatu program maka ada dua peran penyuluh yang terselesaikan, yaitu peran sebagai pembawa pesan/inovasi dan peran sebagai motivator. Jika masyarakat sudah mempunyai semangat untuk berubah maka penyuluh pembangunan tinggal menjalankan perannya sebagai fasilitator yang menjadi pemungkin agar mimpi masyarakat dapat diwujudkan. Penyuluh bisa berperan untuk menjadi penghubung akan sumber daya (resource) yang bisa diakses masyarakat. Selain itu mereka tinggal menjadi konselor jika masyarakat mengalami kendala. Oleh karena itu kegiatan pendokumentasian merupakan hal yang penting. Apalagi beberapa teori menguatkan akan pentingnya media massa dan media sosial sebagai alat bantu komunikasi. Media sosial menjadi kata kunci dan cara baru untuk menjangkau dan menggerakan orang guna melakukan perubahan sosial.

Selain bisa menjadi penyampai informasi dari media sosial, penyuluh juga bisa menjadi produsen gagasan dengan mendokumentasikan peristiwa-peristiwa yang paling menarik untuk dibuat video dan disebarkan ke dampingan yang lain. Bahkan mereka bisa saling tukar video antar penyuluh. Di dunia maya ada banyak video terkait gagasan dan keberhasilan pembangunan yang bisa dipelajari. Penyuluh pembangunan tinggal memasukan kata kunci bidang apa yang akan dicari maka akan muncul puluhan bahkan ratusan video terkait bidang yang dicari tersebut. Cara penyebaran gagasan penyuluh ke dampingan dengan menggunakan video bisa dilakukan dengan dua cara. Cara pertama, penyebaran gagasan bisa dilakukan lewat media sosial, seperti WhatsApp ataupun Facebook ke kelompok dampingan tanpa perlu bertatap muka. Cara kedua tayangan video tersebut bisa diunduh dan ditonton bersamasama dengan menggunakan komputer dan LCD proyektor sehingga penyuluh tetap bisa bertatap 
muka dengan dampingannya.

\section{SIMPULAN}

Penelitian ini menyimpulkan bahwa media sosial menjadi faktor penting sebagai sarana komunikasi pembangunan yang mempengaruhi keberhasilan proses pemberdayaan masyarakat di kelompok Mina Julantoro. Proses tersebut terjadi melalui strategi peniruan dari video yang tayang di media sosial terkait keberhasilan kegiatan serupa di Singosaren Bantul. Keberhasilan pemberdayaan di suatu tempat memberikan trickle down efeck bagi daerah lain. Keberhasilan tersebut mengerakan, ditiru, merembes, menjalar ke komunitas yang lainnya. Masyarakat lebih mudah meniru daripada menjadi inovator dalam program pemberdayaan masyarakat.

Di era perkembangan teknologi yang semakin maju membuat proses peniruan ini dapat menjadi semakin mudah dan cepat. Media sosial mempercepat proses komunikasi dan proses peniruan. Saat ini peniruan akan ide kreatif di satu komunitas tidak harus dilakukan secara langsung dengan melakukan kunjungan ke lokasi. Media sosial seperti YouTube memberikan banyak daftar keberhasilan program pembangunan di banyak daerah dengan teknik yang bermacam-macam. Tayangan media sosial mampu membangkitkan imajinasi masyarakat untuk melakukan peniruan.

Pola peniruan melalui media sosial tidak lagi seperti lampu pijar, namun penyebaran informasi baru melalui media sosial seperti efek bola salju, bahkan dapat menerobos sekat ruang dan waktu. Keberhasilan menjaga selokan tetap bersih di Dusun Singosaren Bantul yang berjarak cukup jauh menjalar ke kelompok Mina Jutantoro di Kota Yogyakarta dan banyak daerah lainnya. .

Berdasarkan kesimpulan tersebut hendaknya penyuluh pembangunan dapat memainkan perannya sebagai pembawa informasi sekaligus penyebar gagasan ke masyarakat menggunakan media sosialteknologi informasi. Keberhasilan program pembangunan di suatu daerah dapat menjadi pemantik bagi pengembangan di kawasan yang lain. Penyuluh dapat mendokumentasikan keberhasilan dampingannya dalam bentuk video dan menyebarkannya ke media sosial.
Jika masyarakat sudah mempunyai ide atau mimpi bagaimana daerahnya akan dibangun (berdasarkan tayangan video) maka peran penyuluh selanjutnya tinggal melanjutkan sebagai pemungkin (enabler), baik itu menyangkut persoalan teknis ataupun menjadi penghubung (broker) ke pemerintah agar mau memberi daya bagi masyarakat.

Berdasarkan paparan sebelumnya dapat disimpulkan bahwa untuk memberi edukasi sekaligus menggerakkan masyarakat guna memanfaatkan potensi yang ada seorang penyuluh pembangunan tidak boleh hanya terpaku pada komunikasi langsung (face to face). Penyuluh pembangunan perlu mempunyai kemampuan membuat film (film maker) dan menyebarkan gagasan tersebut ke seluruh masyarakat sehingga luasnya wilayah dampingan tidak menjadi faktor penghambat program penyuluhan pembangunan.

\section{DAFTAR PUSTAKA}

Badan Pusat Statistik. (2016). Statistik Indonesia 2015: statistical yearbook of Indonesia 2015. Jakarta: Badan Pusat Statistik.

Badan Pusat Statistik. (2018). Profil kemiskinan di Indonesia September 2017. Jakarta. Retrieved from https://www.bps.go.id/ pressrelease/2018/01/02/1413/persentasependuduk-miskin-september-2017mencapai-10-12-persen.html.

Bakhtiar, M. I. (2015). Pengembangan video ice breaking sebagai media bimbingan konseling dalam meningkatkan keterampilan sosial. Jurnal Psikologi Pendidikan \& Konseling, 1(2), 150-163. https://doi.org/https://doi.org/10.26858/ jpkk.v1i2.1816.

Banunaek, M. F., Suminah, \& Karsidi, R. (2017). Pemberdayaan untuk meningkatkan kinerja penyuluh pertanian di Kabupaten Boyolali, Provinsi Jawa Tengah. Jurnal Penyuluhan, 13(2), 210-221. https://doi.org/https://doi. org/10.25015/penyuluhan.v13i2.15169.

Bohang, F. K. (2018). Berapa jumlah pengguna internet Indonesia? Kompas. Retrieved February 22, 2018, from https://tekno. kompas.com/read/2018/02/22/16453177/ berapa-jumlah-pengguna-internetindonesia.

Buchori, B. (2006). Prakata. In Mimpi negara kesejahteraan. Jakarta: LP3ES dan 
Perkumpulan Prakarsa.

Escobar, A. (1995). Encountering development: the making and unmaking of the third world. New Jersey: Princeton University Press.

Hartoyo, N. M., \& Supriadi, D. (2015). Aktivitas sosial melalui penggunaan media sosial: studi kasus Asosiasi Ibu Menyusui Indonesia (AIMI). Jurnal Kajian Komunikasi, 3(1), 1-11. https://doi.org/ https://doi.org/10.24198/jkk.v3i1.7388.

Hermawan, A., Amanah, S., \& Fatchiya, A. (2017). Partisipasi pembudidaya ikan dalam kelompok usaha akuakultur di Kabupaten Tasikmalaya, Jawa Barat. Jurnal Penyuluhan, 13(1), 1-13. https://doi. org/https://doi.org/10.25015/penyuluhan. v13i1.12903.

Jambeck, J. R., Geyer, R., Wilcox, C., Siegler, T. R., Perryman, M., Andrady, A., ... Law, K. L. (2015). Plastic waste inputs from land into the ocean. Science, 347(6223), 768-771. https://doi.org/DOI: 10.1126/ science. 1260352.

Jaya, P. H. I. (2012). Trickle down effect: strategi alternatif dalam pengembangan masyarakat. Jurnal Ilmu Kesejahteraan Sosial, 1(1), 69-85.

Kango, A. (2015). Media dan perubahan sosial budaya. Farabi, 12(1), 20-34.

Karsidi, R. (2001). Paradigma baru penyuluhan pembangunan dalam pemberdayaan masyarakat. Mediator, 2(1), 115-125. https://doi.org/https://doi.org/10.29313/ mediator.v2i1.711.

Kementerian Keuangan Republik Indonesia. (2017). Buku saku dana desa. Jakarta: Kementerian Keuangan Republik Indonesia. Retrieved from https://www. kemenkeu.go.id/media/6750/buku-sakudana-desa.pdf.

Koespradono, G. (2017). Merekayasa fakta menjadi berita: kreatif menulis efektif menggunakan bahasa Indonesia jurnalistik. Yogyakarta: Falsafat.

Kompas. (2018). Kampung berwarna: mengecet tembok, menata mental. Kompas, p. 1. Retrieved March 3, 2018, from https:// kompas.id/baca/utama/2018/03/18/ mengecat-tembok-menata-mental.

Mardikanto, T. (2009). Sistem penyuluhan pertanian. Surakarta: Sebelas Maret
University Press.

Mardikanto, T. (2013). Konsep-konsep pemberdayaan masyarakat: acuan bagi aparat birokrasi, akademisi, praktisi dan peminat/pemerhati pemberdayaan masyarakat. Surakarta: Lembaga Pengembangan Pendidikan (LPP) UNS Press.

Miladi, N. (2016). Social media and social change. DOMES: Digest of Middle East Studies, 25(1), 36-51. https://doi.org/ https://doi.org/10.1111/dome.12082.

Moleong, L. J. (2017). Metodologi penelitian kualitatif. Bandung: PT Remaja Rosdakarya.

Moriansyah, L. (2015). Pemasaran melalui media sosial: antecedents dan consequences. Jurnal Penelitian Komunikasi Dan Opini Publik, 19(3), 187-196. https://doi.org/ http://dx.doi.org/10.33299/jpkop.19.3.346.

Muslim, A. (2017). Analisis kegagalan program nasional pemberdayaan masyarakat dalam membangun kemandirian masyarakat miskin (studi kasus di Provinsi Daerah Istimewa Yogyakarta, Jawa Tengah, dan Jawa Timur). Jurnal Penyuluhan, 13(1), 79-87. https://doi.org/https://doi. org/10.25015/penyuluhan.v13i1.14524.

Putradinata, E. W. (2017). Selokan desa penuh ikan nan cantik: bikin warga pikir ulang buang sampah sembarangan. Retrieved August 30, 2017, from https://www.brilio. net/video/wow/selokan-desa-penuh-ikannan-cantik--170830e.html.

Reza, F. (2016). Strategi promosi penjualan online lazada.co.id. Jurnal Kajian Komunikasi, 4(1), 64-74. https://doi.org/ https://doi.org/10.24198/jkk.v4i1.6179.

Salim, M. G. (2018). Dulu bau dan kotor, selokan di Jogja ini berubah cantik bak di Jepang. Retrieved March 7, 2018, from https:/www.brilio.net/wow/dulu-bau-dankotor-selokan-di-jogja-ini-berubah-cantikbak-di-jepang-180306e.html.

Sudarto. (2018, 18 March). Personal Interview. Sugiyanto. (2012). Analisis pengaruh media iklan televisi terhadap pengambilan keputusan membeli minuman fanta kemasan pada Masyarakat Purworejo. Segmen-Manajemen, 2(1), 1-12.

Sugiyono. (2013). Metode penelitian kuantitatif kualitatif dan R\&D. Bandung: Alfabeta. 
Sumiran. (2018, 13 March). Personal Interview. Triyono, A. (2011). Pengaruh situs jejaring sosial facebook sebagai media alternatif untuk promosi. Jurnal Dian, 11(1), 1-8.

Widjanarko, W., Sulthan, M., \& Lusiana, Y. (2013). Radio siaran publik sebagai media komunikasi masyarakat perdesaan. Jurnal Kajian Komunikasi, 1(2), 119-124. https:// doi.org/https://doi.org/10.24198/jkk. v1i2.6036.

Yasundari. (2016). Hubungan penggunaan instagram dengan motivasi wirausaha pebisnis daring (online) dalam meningkatkan produktivitas. Jurnal Kajian Komunikasi, 4(2), 208-218. 